Article

\title{
Environmental and Economic Assessments and Uncertainties of Multiple Lignocellulosic Biomass Utilization for Bioenergy Products: Case Studies
}

\author{
Yuxi Wang ${ }^{\circledR}$, Jingxin Wang ${ }^{*}$, Xufeng Zhang and Shawn Grushecky \\ Division of Forestry and Natural Resources, West Virginia University, Morgantown, WV 26506, USA; \\ yxwang@mix.wvu.edu (Y.W.); xz0017@mix.wvu.edu (X.Z.); sgrushec@wvu.edu (S.G.) \\ * Correspondence: jxwang@wvu.edu; Tel.: +1-(304)-293-7601
}

Received: 16 October 2020; Accepted: 26 November 2020; Published: 28 November 2020

\begin{abstract}
Life-cycle assessment (LCA) and techno-economic analysis (TEA) were applied to assess the economic feasibility and environmental benefits of utilizing multiple biomass feedstocks for bioenergy products under three different technological pathways with consideration of uncertainties. Three cases were studied for the production of pellets, biomass-based electricity, and pyrolysis bio-oil. A Monte Carlo simulation was used to examine the uncertainties of fossil energy consumption, bioenergy conversion efficiency, stochastic production rate, etc. The cradle-to-gate LCA results showed that pellet production had the lowest greenhouse gas (GHG) emissions, water and fossil fuels consumption ( $8.29 \mathrm{~kg} \mathrm{CO}_{2}$ eq (equivalent), $0.46 \mathrm{~kg}$, and $105.42 \mathrm{MJ}$, respectively). The conversion process presented a greater environmental impact for all three bioenergy products. When producing $46,929 \mathrm{Mg}$ of pellets, 223,380 MWh of electricity, and 78,000 barrels of pyrolysis oil, the net present values (NPV) indicated that only pellet and electricity production were profitable with NPVs of $\$ 1.20$ million for pellets, and $\$ 5.59$ million for biopower. Uncertainty analysis indicated that pellet production showed the highest uncertainty in GHG emission, and bio-oil production had the least uncertainty in GHG emission but had risks producing greater-than-normal amounts of GHG. Biopower production had the highest probability to be a profitable investment with $85.23 \%$.
\end{abstract}

Keywords: bioenergy; biomass utilization; life cycle assessment; techno-economic analysis; uncertainty; bioeconomy

\section{Introduction}

Increasing global energy consumption has resulted in the need to further develop bioenergy products using a variety of renewable materials, including forest residues [1,2], and energy crops [3]. Biomass is considered an environmentally friendly energy resource through its carbon mitigation function [4], and is a preferred alternative to fossil energy resources to reduce greenhouse gas (GHG) emissions [5]. Biomass could be used to produce bioenergy products in a variety of forms, such as firewood, pellets, electricity, ethanol, and biofuels. Since carbon dioxide is consumed during biomass growth, biomass can mitigate the amount of GHG emission generated during the energy conversion [6]. Thus, energy production from biomass has the advantage of reduced GHG emissions.

The utilization of lignocellulosic biomass for biofuels and bioproducts has steadily increased [7]. Current production and application of first-generation biofuels from food crops for biodiesel and bioethanol are well understood [8,9]. However, compared to food crops, lignocellulosic biomass, like forest residues and energy crops, are a major source of cheap and abundant non-food materials available from plants [10]. Therefore, lignocellulosic feedstock can offer the potential to provide novel biofuels or bioenergy, known as the second generation of biofuels [11]. 
In a biorefinery, conversion processes and equipment are integrated to produce power, fuels, or any value-added products from biomass. The biomass conversion processes utilize physical, chemical, biological, and thermal pathways [10]. Densification is a physical conversion that can help overcome the drawback of forest residues and other lignocellulosic biomass materials that always have uneven bulky characteristics [12]. The densification of biomass improves efficiencies in biorefinery facilities and reduces the handling costs of biomass [13]. Pellets are a bioproduct that intensifies the loose biomass and have become popular as solid biofuels [14]. Combustion is a common means of converting biomass to energy, with a proven technology that is low-cost, highly reliable, relatively well understood and commercially available [15]. Lignocellulosic biomass-fired or co-firing power plants can produce electricity, heat or steam using either direct or indirect combustion systems [16]. One major processing route for the production of biofuels from lignocellulosic feedstocks is thermochemical, which produces a wide range of long carbon chain biofuels, such as bio-oil, aviation fuel, ethanol, or reformed fuels [11]. Thermochemical conversion using pyrolysis has been considered an important and promising technique for biofuel production [17]. In most cases, the pyrolysis process is a basic component of thermochemical conversion [15]. Fast pyrolysis is an approach to produce reliable higher energy content liquid fuels from biomass. The pyrolysis-derived liquid fuels can also be blended with petroleum-based fuels such as gasoline or diesel for transportation vehicles [18].

A number of analyses have been conducted on these conversion processes in terms of economics, environmental and life-cycle assessments [2,19-21]. Recent economic analyses indicated that the aforementioned bioenergy products have economic advantages over other alternative fuels [22,23]. A number of techno-economic studies demonstrated the economic feasibility of biomass-based bioenergy production [24-26]. With lower expected feedstock costs and no competition with food, lignocellulosic feedstock was studied as a major bioenergy resource. In a study of biomass-based energy production, techno-economic performance of different plant scale levels in UK were compared, and the economic viability of different processes through a discounted cash flow analysis was analyzed [27]. Trippe et al. [28] examined the biomass-to-liquids and chemicals production by adopting a two-stage concept, and concluded that the cost to produce one normal cubic meter $\left(\mathrm{Nm}^{3}\right)$ of syngas is $\$ 25.07$ $(23 €)$, with the potential to reduce costs 50\% when coal was introduced as a feedstock. As in the study of naphtha and diesel-range fuels' production with the feedstock of biomass via fast pyrolysis pathway, Wright et al. [29] established models with two fixed yearly production rates, respective capital costs and fuel product values for both $\mathrm{n}^{\text {th }}$ plant and pioneer plant. Few studies were conducted to quantify the economic uncertainty and risks associated with a biomass-to-bioenergy project. Batan et al. [30] studied microalgae-based biofuel and characterized the economic feasibility, and their results showed the economic performance and price and cost projections, whereby production cost reaches $\$ 550.10 / \mathrm{bbl}$ (barrels) and $\$ 586.66 / \mathrm{bbl}$ of algal raw oil and diesel, respectively.

Life-cycle assessment (LCA) is a comprehensive procedure for estimating environmental impacts on either cradle-to-gate or cradle-to-grave basis for systematic energy production [31], which both indicate boundary conditions for an LCA study. Usually, the LCA approach for the cradle-to-gate assessment only involves a partial product life cycle from feedstock collection ("cradle") to the time before its transportation to a consumer ("gate") [32], and the cradle-to-grave assessment is the full LCA from resource extraction phase to end-of-life phase ("grave") [33]. Efforts have been made on LCA in the production of multiple conversion pathways of biomass [34-38]. Caputo et al. [34] constructed an LCA model of willow as a short rotation crop to estimate the footprints of willow for energy process, and the system consumed 445.0 to $1052.4 \mathrm{MJ}$ of fossil energy per oven-dry tonne (odt) biomass and provided a large carbon sink that more than compensated carbon emissions. An LCA study by Budsberg et al. [36] on ethanol production with willow biomass as feedstock indicated that life-cycle carbon emissions of ethanol production from willow are carbon negative compared to gasoline-equivalent energy but $169 \%$ more life-cycle freshwater was consumed than the gasoline equivalent. Liu et al. [39] conducted a study using life-cycle inventory (LCI) to investigate the environmental load of multiple bioenergy 
products with three energy crops. Their results showed that willow to bio-product system usually had the lowest environmental impacts and cost compared to perennial grasses.

Monte Carlo simulation is the most commonly recommended approach for uncertainty analysis [40-43]. Uncertainty analysis is not commonly performed in LCAs, although great efforts have been made in classification, definition, and sources of uncertainty as well as methodological aspects for expressing uncertainty [44-46]. At the LCI phase, publicly available LCA databases only provide inventory data with no uncertainty information. The LCA uncertainty of willow-based biomass production was investigated by Caputo et al. [34], and the impacts of a series of parameters including additional herbicide treatment, planting densities and nursery modules were examined. Nguyen et al. [47] evaluated two scenarios for corn-based bio-ethanol supply chains in Kansas with Monte Carlo simulation to examine the uncertainty in GHG emissions, and their results showed that the GHG emissions range from $24 \mathrm{~g} \mathrm{CO}_{2}$ eq/MJ to $41 \mathrm{~g} \mathrm{CO}_{2}$ eq/MJ depending upon the location, size and number of preprocessing depots. There are several economic challenges to overcome in bioenergy production associated with processing technologies [48], feedstock availability and its logistics cost [49], feedstock sustainability [50], financial and technical issues for commercial scale production, and assessment of indirect impacts [51]. Technological and economic uncertainties of eight cellulosic biofuel production pathways via both biochemical and thermochemical conversions were evaluated by Zhao et al. [52]. They reported that the distributions of net present values (NPV) and break-even fuel price for each case, and concluded that the fast pyrolysis and hydro processing pathways are with the relatively lower risk for investors. A techno-economic study [53] with Monte-Carlo analysis compared two bio-oil pathways of two-staged and single-staged upgrading and identified that the two-stage hydrotreating has a relatively low risk for project investment.

Information regarding the quantification of the environmental and economic impacts and their uncertainties in utilizing multiple biomass feedstocks for major bioenergy products at a regional scale have not been fully determined. The objectives of this study were to: (1) conduct a LCA study to examine the environmental impacts of utilizing multiple biomass feedstocks for bioenergy products in the northeastern U.S.; (2) perform an economic analysis of the bioenergy feedstock supply chains; and (3) quantify the uncertainties of the production of bioenergy products in terms of economic feasibility and environmental impacts.

\section{Materials and Methods}

In this study, multiple lignocellulosic bioenergy feedstocks (forest residues, hybrid willow, switchgrass and Miscanthus) were considered for producing three bioenergy products: pellets, bio-power, and liquid biofuels. Base cases were identified with parameter configurations listed in Table 1. Data were primarily collected from regional bioproduct companies: two companies for biomass to pellets, one for biomass to liquid fuels, and one for biomass to biopower in the northeastern U.S. For pellet production, a local pellet plant produced $46,929 \mathrm{Mg}$ of pellets with a sale price at $\$ 185$ per $\mathrm{Mg}$. According to information provided by the pellet fuel company, the retail price ranged from $\$ 180$ to $\$ 210$ per Mg of pellets. For biopower generation, the production yield was calculated as 223,380 MWh per year by setting plant capacity of $30 \mathrm{MW}$ for 365 days operated annually, and the average sale price was 10.5 cents per kilowatt hour (ranged between 8 cents to 26 cents per kilowatt hour) [54]. Many generators may not be able to operate at full capacity due to maintenance issues or weather conditions; thus, capacity factors range from $21.2 \%$ to $93.4 \%$ for various non-fossil fuels [55]. A capacity factor of $85 \%$ was used in this research, based on a study by Klein et. al. [56] for biomass combustion for average cases. For liquid fuels, $78,000 \mathrm{bbl}$ of pyrolysis bio-oil were produced with an assumed sale price of $\$ 54 / \mathrm{bbl}$, according to estimation of the potential minimum selling price by the U.S. DOE (Department of Energy) NREL (National Renewable Energy Laboratory) [57]. Recently, the price of crude oil dropped to its lowest point at $\$ 11.26$ per barrel as of 21 April 2020 [58], and it poses a challenge in producing economic feasible biomass-based pyrolysis oil. Based on a U.S. DOE report [29], the NREL estimates the minimum selling price of a commercially finished fuel made from current 
fast pyrolysis oil is about $\$ 106 / \mathrm{bbl}$. Thus, the price range for pyrolysis bio-oil was $\$ 11.26-106.26 / \mathrm{bbl}$ in this study. By feeding one dry $\mathrm{Mg}$ of lignocellulosic biomass as feedstock, it produced $0.83 \mathrm{Mg}$ of pellet fuel, or 1.53 megawatt hours, or $0.46 / \mathrm{bbl}$ of fast pyrolysis bio-oil. The feedstock price for all cases was assumed to be $\$ 84$ per $\mathrm{Mg}$ based on the DOE's target to lower delivered cost for lignocellulosic biomass than $\$ 84$ per dry Mg in year 2022 [59].

Table 1. Parameter configurations for base case analysis.

\begin{tabular}{cccc}
\hline Parameter & \multicolumn{3}{c}{ Base Cases } \\
\cline { 2 - 4 } & Pellet & Biopower & Biofuel \\
\cline { 2 - 4 } Production technology & pellet mill & combustion with steam & fast pyrolysis \\
Products & pellets & electricity & pyrolysis bio-oil \\
Annual yield & $46,929 \mathrm{Mg}$ & $223,380,000 \mathrm{KWh}$ & 78,000 Barrels $(\mathrm{bbl})$ \\
Product sale price & $\$ 185 / \mathrm{Mg}$ & $\$ 0.105 / \mathrm{KWh}[54]$ & $\$ 54 / \mathrm{bbl}[57]$ \\
Price Range & $\$ 180-210 / \mathrm{Mg}$ & $\$ 0.08-0.26 / \mathrm{KWh}$ & $\$ 11.26-106.26 / \mathrm{bbl}$ \\
Product yield rate (from & $0.83 \mathrm{Mg}$ of pellet & $1.53 \mathrm{MWh}$ of electricity & 2.17 bbl of pyrolysis oil \\
per dry Mg of feedstock) & $\$ 4,403,744$ & $\$ 71,616,960$ & $\$ 106,015,291$ \\
Capital Investment & $\$ 4,046,745$ & $\$ 3,560,469$ & $\$ 612,069$ \\
Annual operation cost & $\$ 84 / \mathrm{dry} \mathrm{Mg}$ & $\$ 84 / \mathrm{dry} \mathrm{Mg}$ & $\$ 84 / \mathrm{dry} \mathrm{Mg}$ \\
Feedstock price & $1 \mathrm{Mg}$ &
\end{tabular}

${ }^{1}$ Provided by Greene Team Pellet Fuel Company.

The baseline model was used to conduct a Monte Carlo simulation for uncertainty analysis related to GHG emission and NPV for bioenergy products derived from lignocellulosic biomass feedstock (Figure 1).

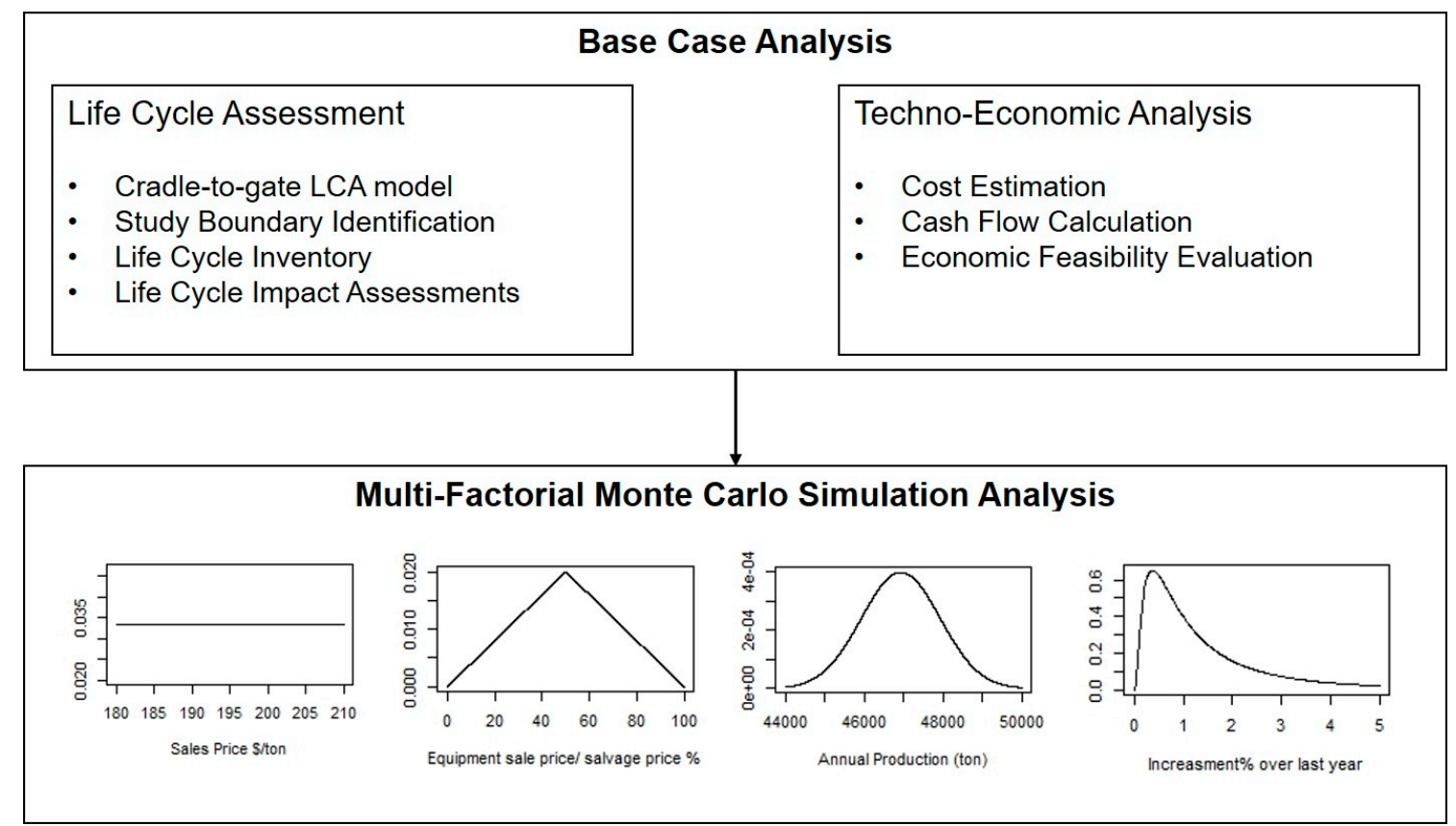

Figure 1. Flow chart of the economic and environmental impacts of biomass for bioenergy products.

\subsection{Life-Cycle Assessment (LCA)}

A cradle-to-gate LCA model framework includes feedstock collection, transportation, storage and preprocessing, bioenergy production (Figure 2). This study focuses on the GHG emissions, water, and fossil fuel consumption. The functional unit (f.u.) of the system is $1000 \mathrm{MJ}$ of energy products. The boundary of this LCA includes raw feedstock handling (harvest/collection), storage, transportation, 
preprocessing, and conversion, following the International Organization for Standardization (ISO)'s LCA standards [60].
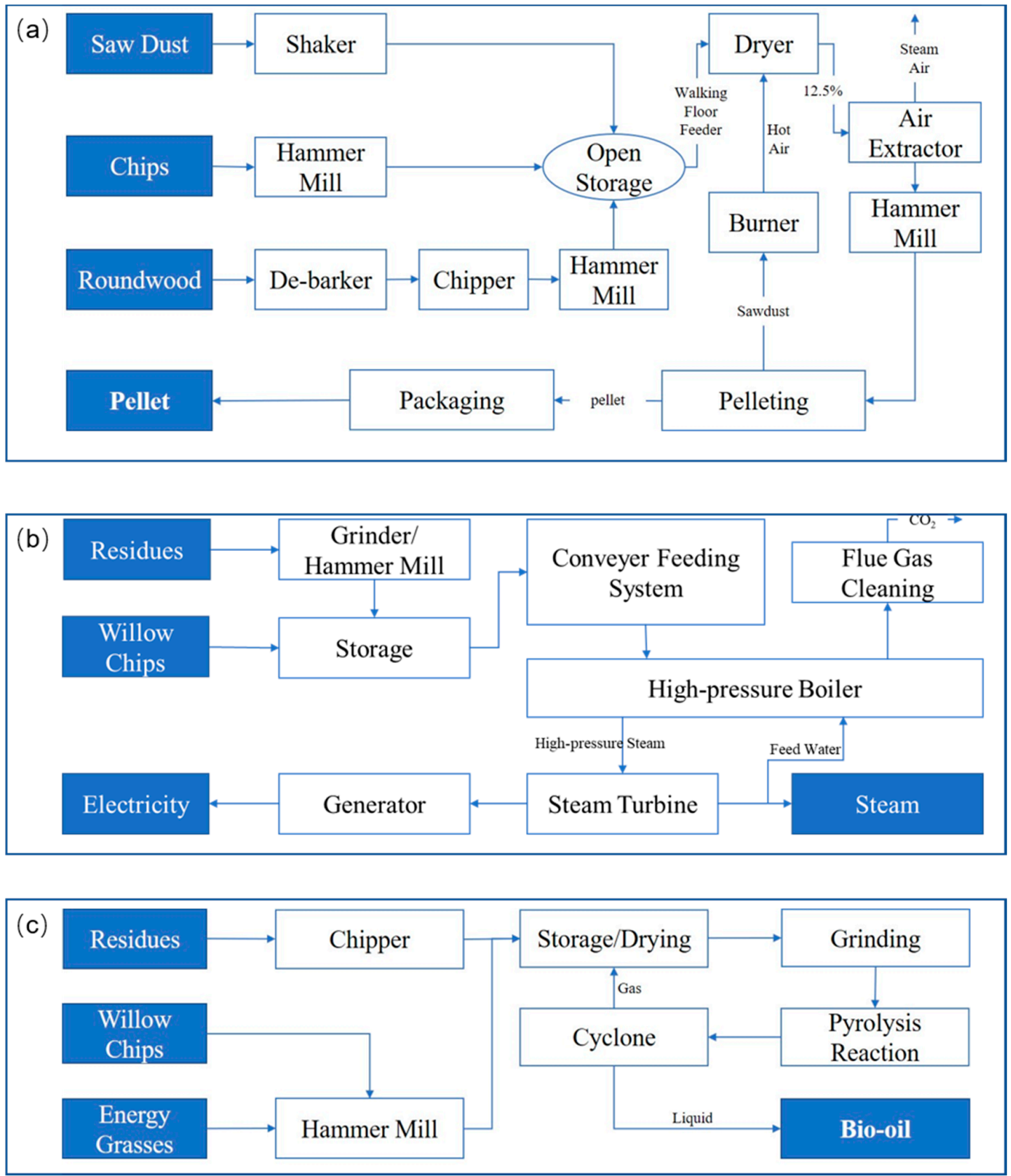

Figure 2. Block flow diagram of multiple-feedstock logistics and production processes, (a) pellet, (b) biopower, and (c) biofuel.

LCI of feedstock collection includes harvesting of logging residues using a grapple loader, grapple skidder and chipper, while establishment of energy crops consists of site preparation, planting, fertilization and cut-and-chip or harvest-and-baling. The fuel consumption of residues harvest system was based on a study by Wu et al. [61]. The US LCI database was also used for the biomass transportation process [62]. The composition of multiple biomass feedstock was based on a study by Wang et al. [63] for an optimized solution of the minimized delivered cost of biomass in the northeastern U.S.

The LCA model was developed using the environmental modeling tool SimaPro [64,65]. The impact of GHGs was calculated using 100-year global warming potentials [66]. All the emissions were converted 
into the carbon dioxide equivalent $\left(\mathrm{kg} \mathrm{CO}_{2} \mathrm{eq}\right)$. The reduction of GHG emissions was calculated as the difference between the emissions from petroleum-derived diesel and the emissions from the energy products by the three technologies in this study. The calculation of water consumption $(\mathrm{kg})$ followed the method by Boulay et al. [67]. Fossil energy consumption (MJ) was calculated based on the Frischknecht's studies [68-70].

\subsection{Mathematical Model for Techno-Economic Analysis (TEA)}

To evaluate the economic feasibility, the processes of the selected bioenergy pathways were first defined (Figure 2) and a range of NPVs was estimated for each pathway scenario based on stochastic analysis of the commodity prices and economic parameters.

The NPV method is a common method for measuring the profitability of an investment with unique advantages compared across other economic metrics, in counting time value of investment and ranking capability [71]. The formulation of the NPV for biomass to bioenergy products is as follows:

$$
\begin{gathered}
N P V=-T I C+\frac{Q_{1}}{(1+\gamma)}+\frac{Q_{2}}{(1+\gamma)^{2}}+\ldots+\frac{Q_{n}}{(1+\gamma)^{n}}-E C+S V \\
=-T I C+\sum_{j=1}^{n} \frac{Q_{j}}{(1+\gamma)^{j}}-E C+S V
\end{gathered}
$$

where,

TIC—-the total initial cost for a bioenergy plant project;

$n$-bioenergy plant lifetime;

$Q_{j}$-net cash flow at any year $j$ after project startup, without equipment replacement costs;

$\gamma$-interest rate;

$E C$ - present value of equipment replacement costs;

$S V$-salvage value.

The annual net cash flow $Q_{j}$ for a bioenergy plant production after the project startup shows a difference between cash inflows and outflows by operating a bioenergy plant over each year, and it was calculated as:

$$
Q_{j}=\left(\left(P Q_{j} *\left(1+\delta_{j}\right) * p\right)-F C_{j}-O C_{j}\right)(1+\epsilon)^{j}
$$

where,

$P Q_{j}$-Quantity of product produced and sold for year $\mathrm{j}$, for instance, quantity of pellets in $\mathrm{Mg}$, amount of electricity in $\mathrm{KWh}$, or quantity of bio-oil in bbl;

$\delta_{j}$-Production increased rate based on previous year;

$p$-Unit selling price;

$F C_{j}$ - Lignocellulosic feedstock cost for year $j$ in dry matter basis;

$O C_{j}$-Operation and maintenance cost at the bioenergy plant for year $j$;

$\epsilon$-Inflation rate.

A constraint was set that the quantity of increased annual production should not exceed the yearly capacity for a bioenergy plant.

$$
P Q_{j} *\left(1+\delta_{j}\right) \leq \text { Capacity }
$$

For quantity of bioenergy products produced and sold $P Q_{j}$,

$$
P Q_{j}=F Q_{j} *(\tau)
$$

where,

$F Q_{j}$-Feedstock quantity in dry $\mathrm{Mg}$ transported to and utilized in facility for year $j$;

$\tau$-Conversion rate, fuels produced by each dry $\mathrm{Mg}$ of feedstock.

For feedstock cost $F C_{j}$ at year $j$,

$$
F C_{j}=\varphi * F Q_{j}
$$


where, $\varphi$ is Feedstock price per dry Mg.

The total present value of equipment replacement costs, $E C$ can be calculated from Equation (6) using the acquisition value for equipment at year zero $A V$. The $E C$ takes into account the equipment initial costs plus the inflation in the period since it began to operate until its replacement, and for each replaced equipment it will be calculated.

$$
E C=\sum_{y} A V \frac{(1+\epsilon)^{y}}{(1+\gamma)^{y}}
$$

where,

$y$-year of the equipment replacement;

$A V$-The acquisition value for equipment at year zero, which is the purchased value of the asset. The salvage value was calculated by the equation:

$$
\mathrm{SV}=\sum_{i}^{N} \operatorname{EIC}_{i}(1-\phi)^{n}
$$

where,

$\mathrm{N}$-Total amount of equipment;

$E I C_{i}$-Equipment purchase cost for equipment $i$;

$\phi$-Depreciation rate;

The total annual cost consists of annualized capital costs (calculated assuming an interest rate of $10 \%[72,73])$, operating and maintenance costs, and biomass feedstock cost. The total installed costs were calculated by a factored estimation [74-76], based on the major equipment required for various production processing. All capital costs are in 2020 U.S. dollars with the equipment cost inflation calculated using the Chemical Engineering Plant Cost Index (CEPCI) [77].

\subsection{Monte Carlo Simulation for Uncertainties}

Monte Carlo simulation is a mathematical technique that performs risk analysis by building models with random variables for decision [78]. In this study, we used this computational algorithm to estimate the environmental impacts and techno-economic benefits of biomass-based energy production. Separate simulation runs with 5000 iterations were conducted. To quantify uncertainty, probability distributions for parameters were used to examine how data behaved [79]. The uniform distribution was applied to "diesel consumption" that all outcomes are equally likely to occur. Triangle distribution was applied to parameters with only known minimum, maximum, and mean values. For parameters "increase rate" and "discount rate", the lognormal distributions implied finite measurements with a minimum value. For those with limits (minimum and maximum values) and known shapes of distribution, Beta distributions were applied to represent these parameters. Monte Carlo analysis was performed for both environmental impacts and economic feasibility in this study (Table 2). 
Table 2. Descriptions of parameters for uncertainty analysis.

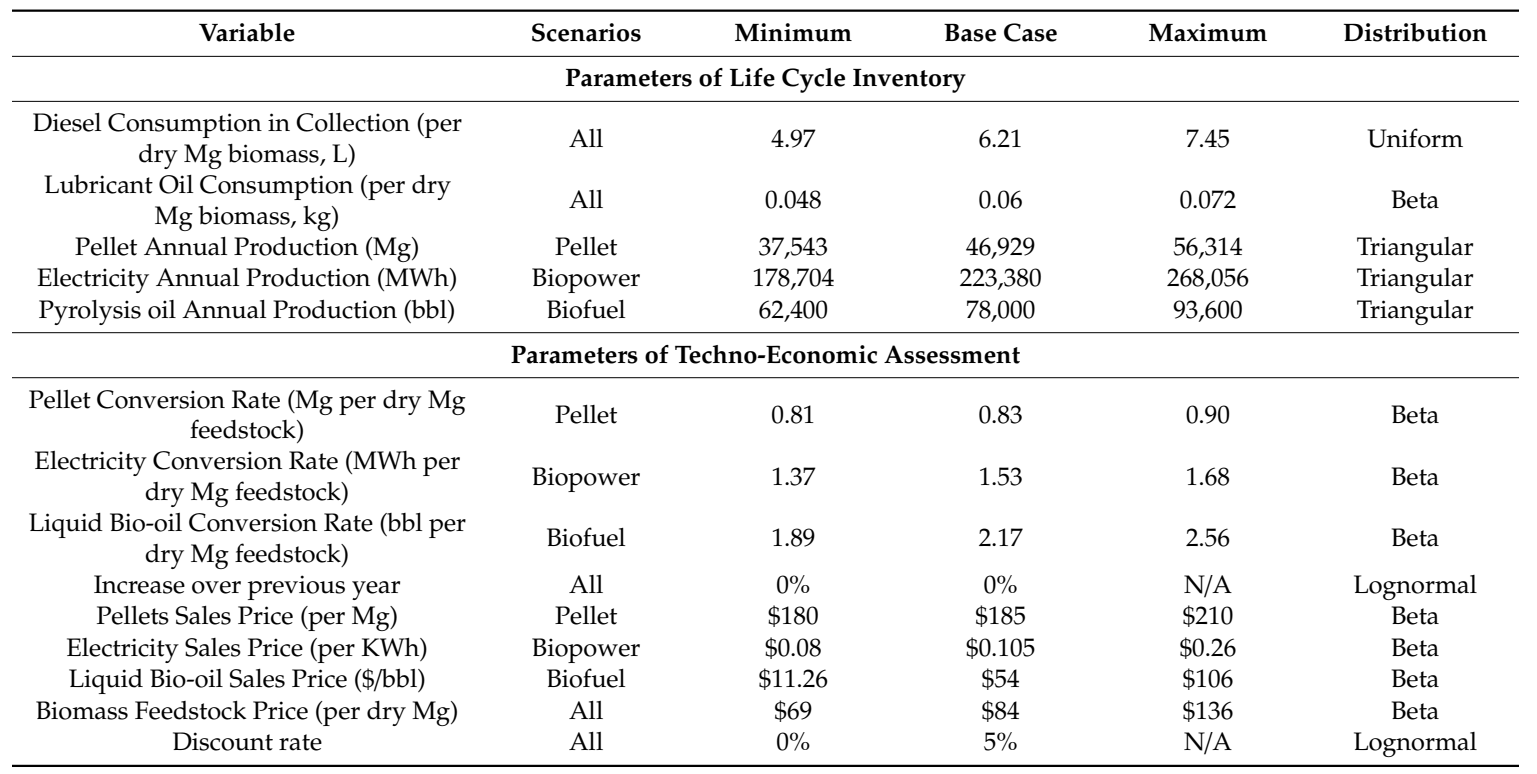

GHG emissions from bioenergy supply chains are critical, since climate change and energy policies often encourage bioenergy as a sustainable GHG mitigation option [80]. The conventional LCA does not perform quantitative uncertainty analysis. However, the reliability of LCA results can be improved by characterizing the associated uncertainty [40]. The uncertainty of GHGs was quantified using various probabilistic methods, including Monte Carlo simulation with knowledge of the underlying probability distribution functions that characterize the model parameters. A total of 1000 random trials were conducted to study the effect of uncertainty. Several factors affecting the life-cycle GHG emissions of biomass-derived fuel products were examined, including the production technology, efficiency of production, and the operation and maintenance of bioenergy production.

Yearly cash flows were generated for the three production systems (pellet, biopower, and bio-oil productions), and the NPVs were derived from these cash flows. Stochastic production rate, production increasing rate, sale price, feedstock price, and discount rate were used to adjust the models. The Monte Carlo implementation results in a set of NPV values, which are represented by their corresponding probability distributions. The greater the number of iterations performed, the better the precision of the uncertainty would be examined.

\section{Results}

\subsection{Life-Cycle Analysis}

The environmental impacts of the three bioenergy technological pathways are listed in Table 3, and all environmental impacts were calculated with f.u. of $1000 \mathrm{MJ}$ for bioenergy production. Pellet production presented the lowest GHG emissions with $8.29 \mathrm{~kg} \mathrm{CO}_{2}$ eq and consumed the least fresh water and fossil fuels. Pyrolysis oil production had the highest environmental impacts for all impact factors. The pyrolysis oil production emitted the highest amount of GHG, which was more than triple that of biopower production, and 6.44 times that of pellet production. Both biopower and pellet production consume a small quantity of fresh water compared with pyrolysis oil production, for 0.73 , and $0.46 \mathrm{~kg}$, respectively. 
Table 3. Life-cycle assessments (LCA) for bioenergy production: pellet, biopower, and biofuel.

\begin{tabular}{|c|c|c|c|c|c|c|}
\hline \multirow{2}{*}{ Products } & \multirow{2}{*}{ Impact Factor } & \multicolumn{4}{|c|}{ Bioenergy Supply Chain Components } & \multirow{2}{*}{$\begin{array}{c}\text { Total LCA } \\
\text { Impacts }\end{array}$} \\
\hline & & $\begin{array}{l}\text { Feedstock } \\
\text { Collection }\end{array}$ & Transportation & $\begin{array}{l}\text { Storage and } \\
\text { Preprocessing }\end{array}$ & Conversion & \\
\hline \multirow{3}{*}{ Pellet } & $\begin{array}{c}\text { Greenhouse Gas } \\
\text { Emission }\left(\mathrm{kg} \mathrm{CO}_{2} \text { eq) }\right.\end{array}$ & 1.239 & 0.294 & 2.394 & 4.368 & 8.29 \\
\hline & & 0.01 & 0.04 & 0.01 & 0.41 & 0.46 \\
\hline & $\begin{array}{c}\text { Fossil Energy } \\
\text { Consumption (MJ) }\end{array}$ & 2.37 & 6.08 & 2.55 & 94.42 & 105.42 \\
\hline \multirow{3}{*}{ Biopower } & $\begin{array}{c}\text { Greenhouse Gas } \\
\text { Emission (kg CO} 2 \text { eq) }\end{array}$ & 3.24 & 6.33 & 2.14 & 3.87 & 15.58 \\
\hline & $\begin{array}{l}\text { Blue Water } \\
\text { Consumption (kg) }\end{array}$ & 0.05 & 0.36 & 0.07 & 0.25 & 0.73 \\
\hline & $\begin{array}{c}\text { Fossil Energy } \\
\text { Consumption (MJ) }\end{array}$ & 6.77 & 53.93 & 18.43 & 107.04 & 186.17 \\
\hline \multirow{3}{*}{ Biofuel } & $\begin{array}{c}\text { Greenhouse Gas } \\
\text { Emission }\left(\mathrm{kg} \mathrm{CO}_{2} \mathrm{eq}\right)\end{array}$ & 2.93 & 3.74 & 0.62 & 23.29 & 30.58 \\
\hline & $\begin{array}{l}\text { Blue Water } \\
\text { Consumption (kg) }\end{array}$ & 0.12 & 0.36 & 0.08 & 3.84 & 4.40 \\
\hline & $\begin{array}{c}\text { Fossil Energy } \\
\text { Consumption (MJ) }\end{array}$ & 16.93 & 43.42 & 16.26 & 602.38 & 678.98 \\
\hline
\end{tabular}

Total impact percentages were analyzed and summarized by supply chain components for pellets, biopower and bio-oil (Figure 3). Feedstock transportation contributed most to the GHG emission and blue water consumption (BWC) when producing electricity (biopower) with $40.66 \%$ of total GHG emission, and $48.81 \%$ of BWC. The conversion process for pellet and bio-oil (biofuel) production had more influence on GHG (with proportions of $52.66 \%$ and $76.17 \%$, respectively) and BWC (with proportions of $88.53 \%$ and $87.27 \%$, respectively). All four processes (including feedstock collection, transportation, storage and preprocessing, and conversion) for biopower production contributed more than $10 \%$ of GHGs. Storage and preprocessing for bio-oil production accounted for very low portions (2.03\%) of the total GHG emission, but it contributed $28.86 \%$ of GHG when producing pellets. When producing electricity from lignocellulosic biomass, transportation $(48.81 \%)$, and conversion ( $34.64 \%$ ) consumed the most water. The conversion portion of the bioenergy supply chain consumed the largest amount of fossil energy in all three bioenergy productions, which all exceeded $50 \%$ of total fossil fuel consumption. Specifically, the conversion processes consumed $89.57 \%$ and $88.72 \%$ of total fossil energy to produce pellets and bio-oil. For biopower production, $57.49 \%$ of fossil energy was consumed in combustion and $28.79 \%$ of fossil fuel was used in the feedstock transportation process, with $9.90 \%$ for storage and preprocessing, and $3.64 \%$ for feedstock collection. 


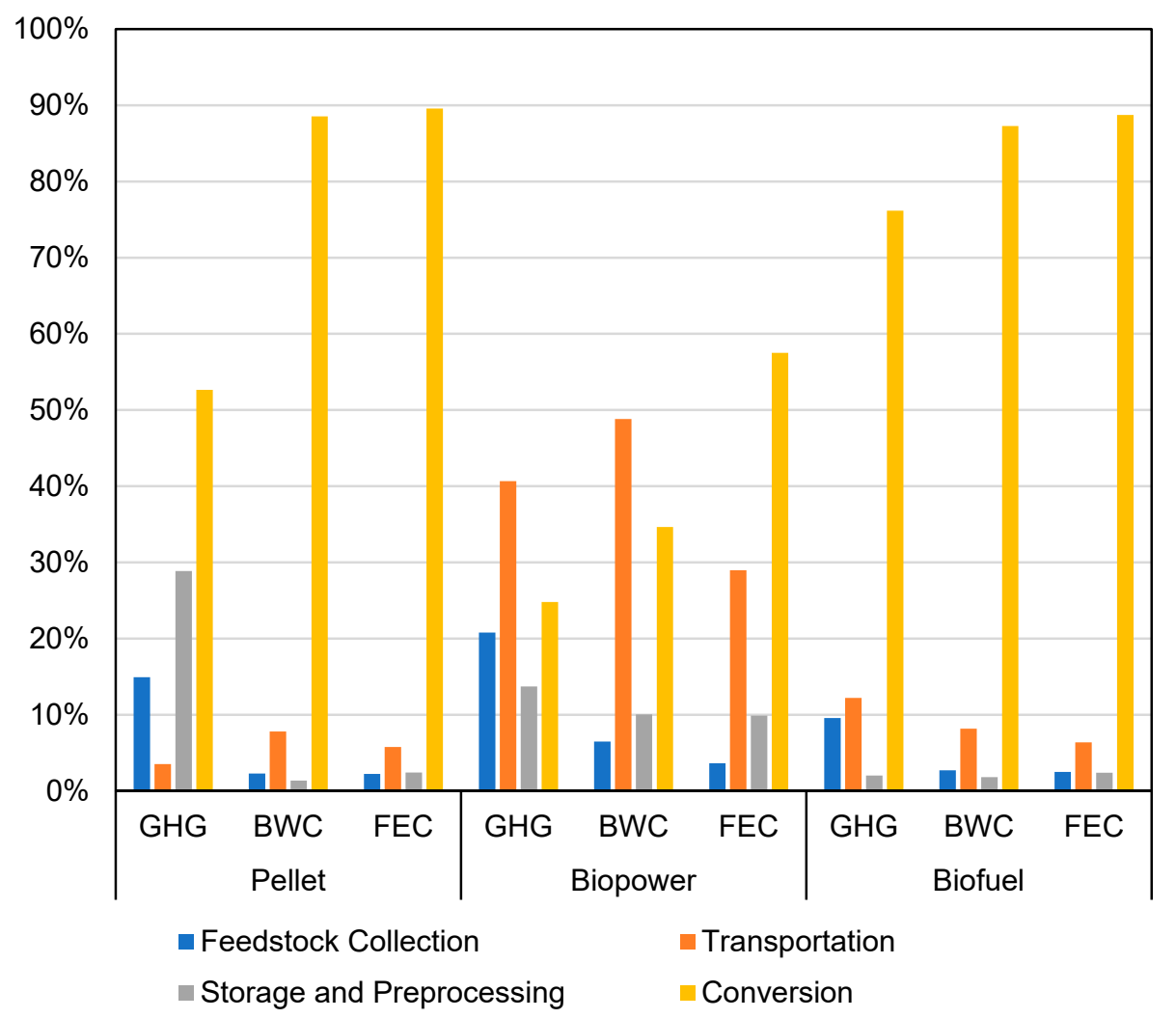

Figure 3. Percentages of the total impact of greenhouse gas emission (GHG), blue water consumption (BWC), and fossil energy consumption (FEC) by supply chain components for pellet, biopower, and biofuel.

\subsection{Techno-Economic Analysis}

Based on economic assessment for multi-feedstock multi-pathways bioenergy production, the economic evaluations are summarized in Table 4. In the first year of plant life, there are only cash outflows with capital investment (e.g., equipment installations), while energy products would be produced and sold starting from the second year.

Table 4. Economic evaluation for three bioenergy production cases: pellet, biopower, and biofuel.

\begin{tabular}{cccc}
\hline Parameter & \multicolumn{3}{c}{ Bioenergy Production Cases } \\
\cline { 2 - 3 } & Pellet & Biopower & Biofuel \\
\cline { 2 - 3 } Plant life (year) & Bioenergy production summary & 20 \\
Feedstock consumption (dry Mg) & 16 & 25 & 666,900 \\
Bioenergy production & 848,114 & $3,505,217$ & $1,482,000 \mathrm{bbl}$ \\
& $703,935 \mathrm{Mg}$ & $5,361,120 \mathrm{MWh}$ & \\
Total investment cost (\$) & Economic feasibility summary & $106,015,291$ \\
Total feedstock cost $(\$)$ & $4,403,744$ & $149,550,000$ & $56,019,600$ \\
Total operating cost (\$) & $71,241,614$ & $294,438,187$ & $11,629,319$ \\
Total revenue $(\$)$ & $50,701,175$ & $85,451,256$ & $80,028,000$ \\
Net Present Value (NPV) $(\$)$ & $139,236,253$ & $565,623,106$ & $(98,998,847)$ \\
Discount rate $(\%)$ & $1,201,069$ & $5,588,915$ & 5 \\
\hline
\end{tabular}

Total biomass feedstock consumption and bioenergy mass production are summarized. With a consumption of 848,114 dry Mg of biomass feedstock, a pellet plant could produce $703,935 \mathrm{Mg}$ of pellet products, which would bring a total of $\$ 139.23$ million in revenue, with a NPV of $\$ 1.20$ million over 
16 years. A biopower plant would utilize around four times the amount of feedstock, which could bring 4.06 times the revenue ( $\$ 565.62$ million) when compared to a pellet plant. For biopower production, the NPV was $\$ 5.59$ million with discount rate of $5 \%$. The total amount of biomass feedstock consumed for bio-oil production was similar to pellet production but resulted in a much lower NPV at $-\$ 98.14$ million. The capital investment cost for bio-oil production represented the largest contribution with $61.05 \%$, while feedstock cost accounted for $56.39 \%$ and $55.61 \%$ of the total cost for producing pellets and electricity, respectively. Production costs averaged $\$ 173.23 / \mathrm{Mg}$ for pellets, $\$ 0.07 / \mathrm{KWh}$ for biopower, and $\$ 45.65 / \mathrm{bbl}$ for pyrolysis fuels.

A discount rate is used in discounted cash flow analysis to compute a NPV [81], and the general rule of thumb for selecting an appropriate discount rate is that it would equal an investor's required rate of return [82]. The NPVs of bioenergy plants via three conversion pathways were analyzed based on $0-30 \%$ discount rates (Figure 4). For pellet production, the NPV ranged from $\$ 2.89$ million to $\$ 0.21$ million for discount rate $0 \%$ to $10 \%$ accordingly. The biopower plant would be profitable when the NPV ranged from $\$ 30.60$ million to $\$ 5.59$ million and when the discount rate was less than or equal to $5 \%$. The NPV dropped dramatically as discount rate increased. For the pyrolysis oil production, it was never profitable at the range of options used, even though the discount rate was as low as $0 \%$.
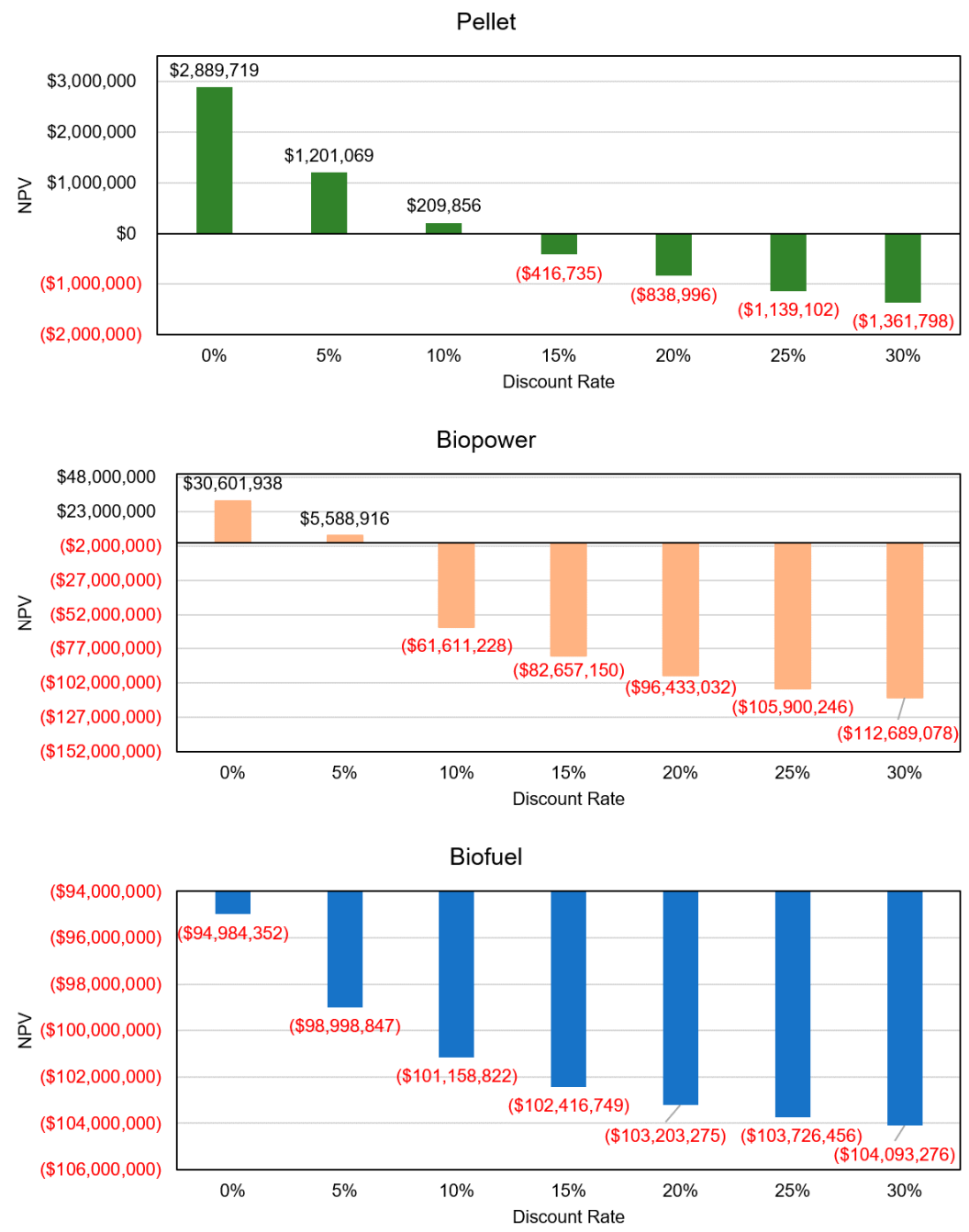

Figure 4. The impacts of discount rate on net present value for pellet, biopower, and biofuel production. 


\subsection{Uncertainties of the Environmental and Economic Impacts}

GHG emissions from bioenergy supply chains are critical to their sustainability and GHG mitigation potential. The uncertainties of GHG for three bioenergy products were examined using Monte Carlo simulations (Figure 5). In Figure 5, the right tail of pellet and the left tail of bio-power simulations were almost overlapping. To produce $1000 \mathrm{MJ}$ bioenergy products via three technology pathways, bio-fuel production would likely have the highest GHG emission at $51.2 \mathrm{~kg} \mathrm{CO}_{2}$ eq. Emissions from electricity generated from lignocellulosic biomass ranged from 15.4 to $15.9 \mathrm{CO}_{2} \mathrm{~kg}$ eq GHG emission per 1000 MJ. Based on the Monte Carlo simulations, bio-fuel production had a compacted distribution of GHG emission which was right skewed, ranging from 21.9 to $51.2 \mathrm{CO}_{2} \mathrm{~kg}$ eq per $1000 \mathrm{MJ}$. The GHG emission simulation for pellet production showed a large variation with GHG from 7.4 to $10.5 \mathrm{CO}_{2} \mathrm{~kg}$ eq per $1000 \mathrm{MJ}$. Among three bioenergy products, pellet production showed the highest uncertainty in GHG emission, while bio-oil production had the least uncertainty in GHG emission but faced risks by producing greater-than-normal amount of GHG.

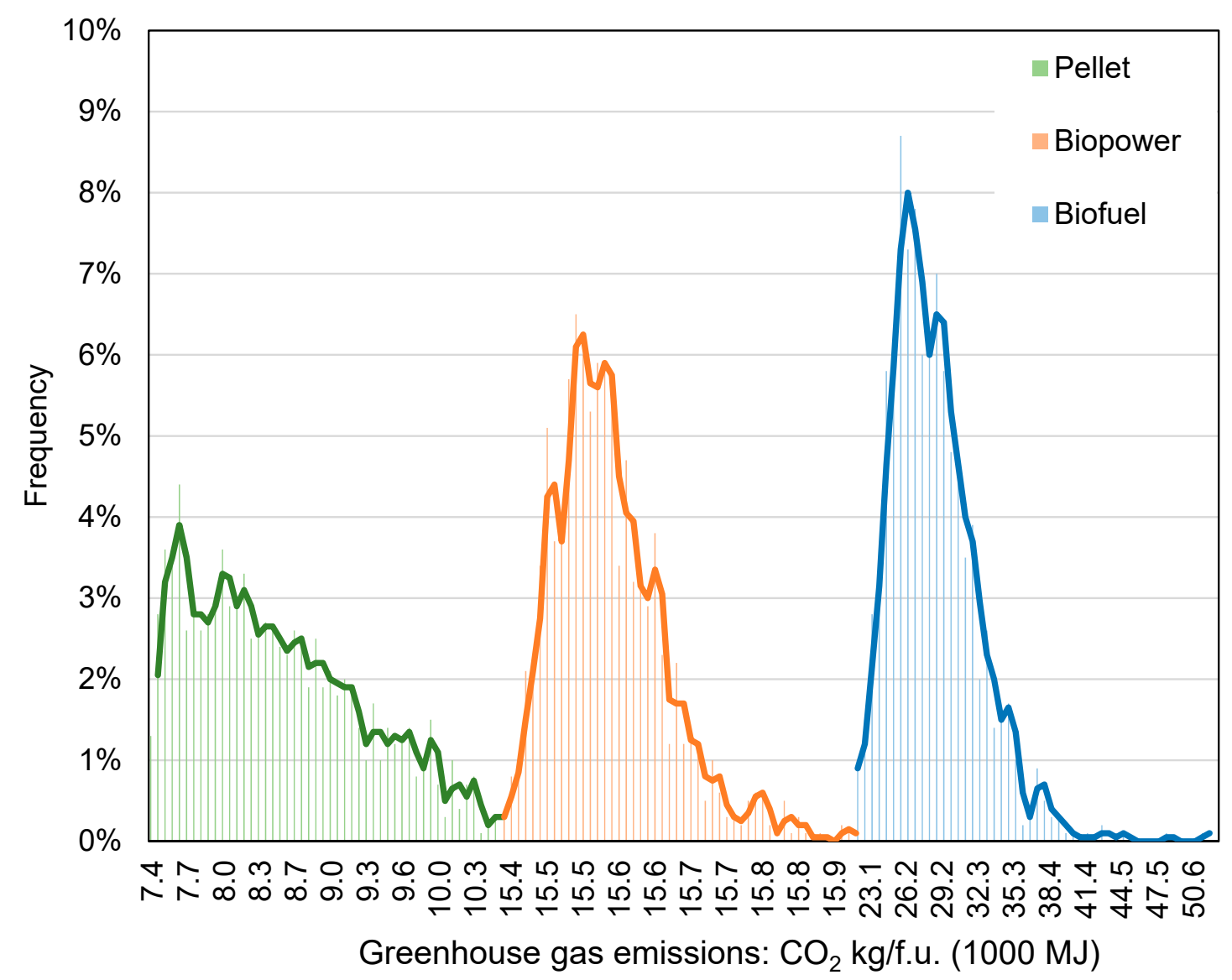

Figure 5. Uncertainty of greenhouse gas emission for pellet, biopower, and biofuel.

Five sensitive variables were accessed in terms of NPVs. After 5000 iterations, the NPV values converged via Monte Carlo simulation, when related parameter uncertainties were considered (Figure 6). 

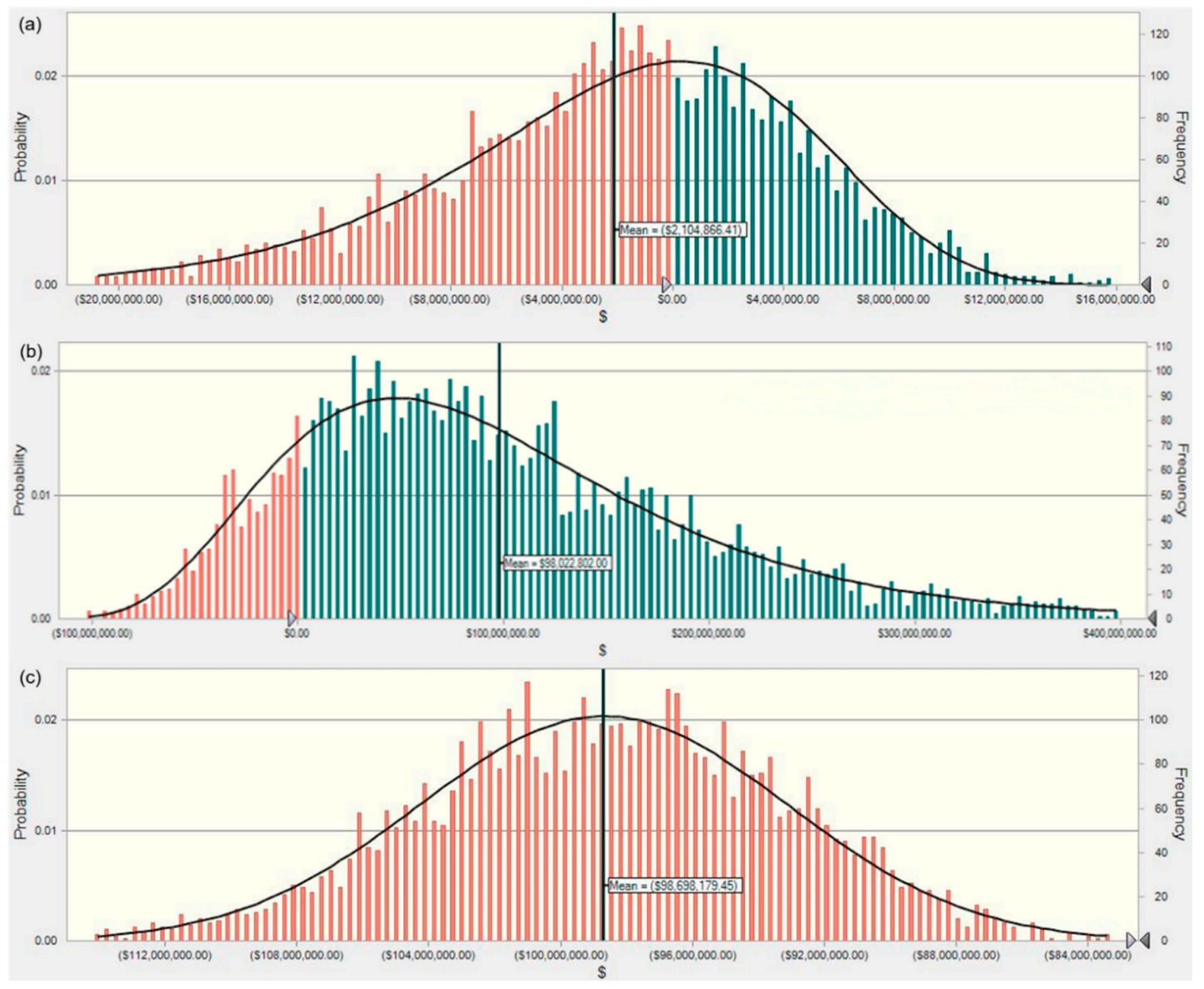

Figure 6. Fitness of statistical distributions of uncertainties: (a) pellet, (b) biopower, and (c) biofuel.

For pellet fuel production, the distribution had an average NPV of $-\$ 2,104,886$ with a $39.58 \%$ of probability of being a profitable investment. To determine the best fitted distribution, the Anderson-Darling factor was calculated. A Weibull distribution showed the best fit with lowest Anderson-Darling factor of 4.04. In the biopower production pathway, the probability of being profitable was $85.23 \%$ with the uncertainty factors introduced. The forecast NPV ranged from $-\$ 15.28$ million to $\$ 233.29$ million for an $80 \%$ credible interval. A Lognormal distribution with a mean value of $-\$ 2.99$ million, and standard deviation value of $\$ 9.08$ million, was best for determining the probability prediction for biopower production. The probability for a biofuel plant to be profitable was zero. A beta distribution was best for representing the uncertainty distribution.

\section{Discussion}

\subsection{Environmental Impacts}

Power generation emits significant amounts of GHG, which are a combination of $\mathrm{CO}_{2}, \mathrm{CH}_{4}$, and $\mathrm{N}_{\mathrm{x}} \mathrm{O}$ and are typically associated with the upstream processes of power generation. Spath et al. [83] studied the GHG emissions for biomass and conventional fossil systems to generate electricity, and found the biomass direct-fired system have global warming potential $-148 \%$ lower compared to a traditional coal-fired power plant, and 99\% lower than fossil fuel combustion. Hsu [84] studied the GHG emissions for biomass-based pyrolysis oil, and showed that greenhouse gas emissions could be reduced by around $50 \%$ from pyrolyzed biofuels compared to fossil fuels. To produce every $1000 \mathrm{MJ}$ of bioenergy, bio-oil production generated the highest GHG emission, and consumed most fresh water and fossil energy among all three bioenergy products. In a pyrolysis oil study by Steele et al. [85], the results 
showed the global warming potential for pyrolysis bio-oil production is $32 \mathrm{~kg} \mathrm{CO}_{2}$ eq, which is very close to $30.58 \mathrm{~kg} \mathrm{CO}_{2}$ eq of GHG emission in this study. Although creating higher GHG emissions than the other two bioenergy products, pyrolysis technology is advancing at a rapid rate and has a promising potential for commercial conversion of biomass to fuels.

Contributions to the total GHG emissions of biorefinery systems were different based on conversion pathways. For bio-oil production, pyrolysis conversion was the only crucial process to determine how much GHG emits. However, when producing pellets, feedstock collection, storage and processing, and pelletizing all played large role in determining the final GHG balance. It is the same for biopower production in that all processes contribute more than $10 \%$ of the total GHG emission. The changes among different bioenergy products is explained by different utilization of energy at each of the facilities. Based on the study by Cherubini and Jungmeier [86], the largest fraction of total GHG emission originated from diesel/gasoline consumption, followed by electricity from natural gas, heat and others. The production of pellets showed lower GHG emissions than the other two products, primarily due to lower electricity consumption in pellet mills with less processing $[19,85]$. Even though energy consumption is usually high for biomass power generation [87], the heat and electricity generated could be reused to some extent to reduce fossil energy consumption.

\subsection{Economic Feasibility}

For bioproduct investment, the major capital cost items for a bioenergy production system include the processing and controlling equipment. System cost intensity tends to decrease as the system size increases, but this could increase significantly with feedstock costs [88]. Usually the scale of a biopower plant or a biofuel refinery is much larger, and a larger facility will demand more biomass with greater biomass handling costs [89]. Locating multiple smaller facilities can reduce transportation distance of biomass delivery, but would potentially increase total costs.

Feedstock cost occupied a large proportion of the total impact on the final production costs. In a study of biomass-based transportation fuel [29], the cost of biomass as feedstock is an important factor affecting the sensitivity of the total cost and the feedstock cost varies among feedstock supply/demand locations all year round. Consequently, the feedstock cost also proved to be an important parameter influencing the final product value from biomass [90]. It is critical to lower feedstock cost by minimizing delivery cost through logistic optimization [63]. Biomass logistics modeling and optimization have long been on a single biomass feedstock at a relatively small scale, and this study showed that it is necessary to focus on multiple feedstocks at relatively large commercial scale. In biomass logistics optimization, biomass feedstock with issues such as low bulk density, being spatially dispersed, and having high mass loss during handling always needs to be considered to lower the biomass delivered cost. There are various feedstocks available in the northeastern U.S. that could be incorporated including energy grass, short rotation woody crops such as hybrid willow, and forest residues.

\subsection{Uncertainty and Risks Analysis}

In bioenergy production with renewable sources, the use of the Monte Carlo method has advantages when compared to traditional sensitivity analysis. Monte Carlo simulation provides a dynamic approach to assess bioenergy production environmentally and economically [91].

When counting uncertainty factors for the three bioenergy products, 10,000 iterations of Monte Carlo simulation were made. Pellet production showed a flatter distribution than the other cases which represented the highest uncertainty in GHG emission. This suggests that any slight change in environmental impact factors for pellet fuel production could easily raise the GHG emission. For the biofuel scenario, its environmental impacts would be less affected with little uncertainty, even though it had the highest GHG emission.

Fossil fuel prices have a great impact on the bioenergy market, especially for pyrolysis oil production from biomass. In this study, the biofuel case always showed a negative NPV for a sale price ranging from $\$ 11.26$ to $\$ 106 / \mathrm{bbl}$. However, the bio-oil plant would be profitable if the market 
price could rise to $\$ 135 / \mathrm{bbl}$, and the NPV would be as high as $\$ 2.52$ million with a $5 \%$ discount rate. When accounting for multiple economic uncertainty factors, the low profitability probability $(39.58 \%)$ for a pellet plant implies a high risk in investment, compared to the high probability $(85.23 \%)$ for the biopower plant. The smaller scale of the bioenergy plant makes it more fragile to the changes in the financial environment and biomass and bioenergy markets. To increase the assurance of investment profitability, adding additional processing to upgrade products that could lead to price premiums would provide financial benefits.

\section{Conclusions}

This paper provides a dynamic approach to conduct an integrated life-cycle and techno-economic assessment (TEA) for three bioenergy products utilizing multiple lignocellulosic biomass as feedstock. Results of the LCA and TEA provide insight for commercial-level decision making with regard to bioenergy production alternatives and investment potentials. Results can also inform potential policy makers aiming at facilitating growth in the bioenergy and bioproducts industries in the Northeastern United States.

The LCAs for each supply chain component show different patterns for pellet, biopower, and biofuel production. The variance of environmental burden and cost were mostly explained by the differences of conversion pathways of the products. Results of the LCA show that pyrolysis bio-oil production had the highest environmental impacts, and pellet production had the lowest environmental impacts for GHG emissions, water and fossil fuel consumption.

The economic feasibility of multiple biomass feedstocks for bioenergy products is essential for the scale-up of various technologies. Separate process-based technical cost models were developed for the three established bioenergy production processes, and the cases of pellet and biopower production showed profitable under certain plant assumptions and circumstances.

Analytical approaches like Monte Carlo simulation help us make more accurate decisions by applying a large number of iterations. For GHG emission, pellet production shows higher uncertainty than the other two bioenergy products. For financial evaluation, there is greater chance of a profitable investment for biopower production.

Author Contributions: Conceptualization, J.W. and Y.W.; methodology, J.W. and Y.W.; software, Y.W. and X.Z.; formal analysis, Y.W.; writing-original draft preparation Y.W.; writing-review and editing, Y.W., J.W., X.Z. and S.G.; visualization, Y.W.; funding acquisition, J.W. All authors have read and agreed to the published version of the manuscript.

Funding: This research was funded by US Department of Energy, Office of Energy Efficiency and Renewable Energy, Bioenergy Technology Office (Award \# EE0006638), and the Agriculture and Food Research Initiative Competitive Grant No. 2019-67020-29287 and 2020-68012-31881 from the USDA National Institute of Food and Agriculture.

Conflicts of Interest: The authors declare no conflict of interest. The funders had no role in the design of the study; in the collection, analyses, or interpretation of data; in the writing of the manuscript; or in the decision to publish the results.

\section{Abbreviations}

$\begin{array}{ll}\text { bbl } & \text { barrel of oil } \\ \text { BWC } & \text { blue water consumption } \\ \text { CEPCI } & \text { Chemical Engineering Plant Cost Index } \\ \text { f.u. } & \text { functional unit } \\ \text { GHG } & \text { greenhouse gas } \\ \text { ISO } & \text { International Organization for Standardization } \\ \text { LCA } & \text { life-cycle assessment } \\ \text { LCI } & \text { life-cycle inventory }\end{array}$




$\begin{array}{ll}\text { Nm3 } & \text { normal cubic meter } \\ \text { NPV } & \text { net present value } \\ \text { odt } & \text { oven-dry tonne } \\ \text { TEA } & \text { techno-economic analysis }\end{array}$

\section{References}

1. Searle, S.; Malins, C.J. Waste and residue availability for advanced biofuel production in EU Member States. Biomass Bioenergy 2016, 89, 2-10. [CrossRef]

2. Sowlati, T. Modeling of forest and wood residues supply chains for bioenergy and biofuel production. In Biomass Supply Chains for Bioenergy and Biorefining; Woodhead Publishing: Cambridge, UK, 2016; pp. 167-190.

3. Robertson, G.P.; Hamilton, S.K.; Barham, B.L.; Dale, B.E.; Izaurralde, R.C.; Jackson, R.D.; Landis, D.A.; Swinton, S.M.; Thelen, K.D.; Tiedje, J.M. Cellulosic biofuel contributions to a sustainable energy future: Choices and outcomes. Science 2017, 356, eaal2324. [CrossRef] [PubMed]

4. Demirbaş, A. Biomass resource facilities and biomass conversion processing for fuels and chemicals. Energy Convers. Manag. 2001, 42, 1357-1378. [CrossRef]

5. U.S. Department of Energy. Biomass Basics: The Facts about Bioenergy; Energy Efficiency \& Renewable Energy, EE-1201; U.S. Department of Energy: Washington, DC, USA, 2015.

6. Morais, A.R.C.; Lopes, A.M.D.C.; Bogel-Łukasik, R. Carbon Dioxide in Biomass Processing: Contributions to the Green Biorefinery Concept. Chem. Rev. 2015, 115, 3-27. [CrossRef] [PubMed]

7. Cherubini, F. The biorefinery concept: Using biomass instead of oil for producing energy and chemicals. Energy Convers. Manag. 2010, 51, 1412-1421. [CrossRef]

8. Novo, A.; Jansen, K.; Slingerland, M. The sugarcane-biofuel expansion and dairy farmers' responses in Brazil. J. Rural. Stud. 2012, 28, 640-649. [CrossRef]

9. Elander, R.T.; Putsche, V.L. Ethanol from corn: Technology and economics. In Handbook on Bioethanol; CRC Press LLC: Boca Raton, FL, USA, 2018; pp. 329-349.

10. Naik, S.; Goud, V.V.; Rout, P.K.; Dalai, A.K. Production of first and second generation biofuels: A comprehensive review. Renew. Sustain. Energy Rev. 2010, 14, 578-597. [CrossRef]

11. Sims, R.E.; Mabee, W.; Saddler, J.N.; Taylor, M. An overview of second generation biofuel technologies. Bioresour. Technol. 2010, 101, 1570-1580. [CrossRef]

12. Stevens, C.V.; Verhé, R. Renewable Bioresources: Scope and Modification for Non-Food Applications; John Wiley \& Sons: Hoboken, NJ, USA, 2004.

13. Yancey, N.A.; Tumuluru, J.S.; Wright, C.T. Drying, Grinding and Pelletization Studies on Raw and Formulated Biomass Feedstock's for Bioenergy Applications. J. Biobased Mater. Bioenergy 2013, 7, 549-558. [CrossRef]

14. Goliński, T.; Foltynowicz, Z. Pellet-a key to biomass energy. Inter. J. Econ. Pract. Theor. 2012, 2, $197-204$.

15. Bhaskar, T.; Bhavya, B.; Singh, R.; Naik, D.V.; Kumar, A.; Goyal, H.B. Thermochemical Conversion of Biomass to Biofuels. In Biofuels; Pandey, A., Larroche, C., Ricke, S.C., Dussap, C.-G., Gnansounou, E., Eds.; Academic Press: Amsterdam, The Netherlands, 2011; Chapter 3; pp. 51-77.

16. Liu, W.; Wang, J.; Bhattacharyya, D.; Jiang, Y.; DeVallance, D. Economic and environmental analyses of coal and biomass to liquid fuels. Energy 2017, 141, 76-86. [CrossRef]

17. Zhang, J.; Zhang, X. The thermochemical conversion of biomass into biofuels. In Biomass, Biopolymer-Based Materials, and Bioenergy; Verma, D., Fortunati, E., Jain, S., Zhang, X., Eds.; Woodhead Publishing: Cambridge, UK, 2019; pp. 327-368.

18. Lehto, J.; Oasmaa, A.; Solantausta, Y.; Kytö, M.; Chiaramonti, D. Review of fuel oil quality and combustion of fast pyrolysis bio-oils from lignocellulosic biomass. Appl. Energy 2014, 116, 178-190. [CrossRef]

19. Fantozzi, F.; Buratti, C. Life cycle assessment of biomass chains: Wood pellet from short rotation coppice using data measured on a real plant. Biomass Bioenergy 2010, 34, 1796-1804. [CrossRef]

20. Sultana, A.; Kumar, A. Ranking of biomass pellets by integration of economic, environmental and technical factors. Biomass Bioenergy 2012, 39, 344-355. [CrossRef]

21. Loock, R. Biomass Power Plant. U.S. Patent Application No. US2011/0183410A1, 28 July 2011.

22. Ehrlich, P. Faculty Opinions recommendation of Environmental, economic, and energetic costs and benefits of biodiesel and ethanol biofuels. Proc. Natl. Acad. Sci. USA 2006, 103, 11206-11210. 
23. Cadenas, A.; Cabezudo, S. Biofuels as Sustainable Technologies: Perspectives for Less Developed Countries. Technol. Forecast. Soc. Chang. 1998, 58, 83-103. [CrossRef]

24. Arena, U.; Gregorio, F.D.; Santonastasi, M. A techno-economic comparison between two design configurations for a small scale, biomass-to-energy gasification based system. Chem. Eng. J. 2010, 162, 580-590. [CrossRef]

25. Pootakham, T.; Kumar, A. Bio-oil transport by pipeline: A techno-economic assessment. Bioresour. Technol. 2010, 101, 7137-7143. [CrossRef]

26. Brown, T.R.; Wright, M.M. Techno-economic impacts of shale gas on cellulosic biofuel pathways. Fuel 2014, 117, 989-995. [CrossRef]

27. Patel, C.; Lettieri, P.; Germanà, A. Techno-economic performance analysis and environmental impact assessment of small to medium scale SRF combustion plants for energy production in the UK. Process. Saf. Environ. Prot. 2012, 90, 255-262. [CrossRef]

28. Trippe, F.; Fröhling, M.; Schultmann, F.; Stahl, R.; Henrich, E. Techno-economic assessment of gasification as a process step within biomass-to-liquid (BtL) fuel and chemicals production. Fuel Process. Technol. 2011, 92, 2169-2184. [CrossRef]

29. Wright, M.M.; Daugaard, D.E.; Satrio, J.A.; Brown, R.C. Techno-economic analysis of biomass fast pyrolysis to transportation fuels. Fuel 2010, 89, S2-S10. [CrossRef]

30. Batan, L.Y.; Graff, G.D.; Bradley, T.H. Techno-economic and Monte Carlo probabilistic analysis of microalgae biofuel production system. Bioresour. Technol. 2016, 219, 45-52. [CrossRef] [PubMed]

31. Tan, R.R.; Culaba, A.B.; Purvis, M.R. POLCAGE 1.0—A possibilistic life-cycle assessment model for evaluating alternative transportation fuels. Environ. Model. Softw. 2004, 19, 907-918. [CrossRef]

32. Cao, C. Sustainability and life assessment of high strength natural fibre composites in construction. In Advanced High Strength Natural Fibre Composites in Construction; Fan, M., Fu, F., Eds.; Woodhead Publishing: Cambridge, UK, 2017; pp. 529-544.

33. Koura, J.; Manneh, R.; Belarbi, R.; El Khoury, V.; El Bachawati, M. Comparative cradle to grave environmental life cycle assessment of traditional and extensive vegetative roofs: An application for the Lebanese context. Int. J. Life Cycle Assess. 2020, 25, 423-442. [CrossRef]

34. Caputo, J.; Balogh, S.B.; Volk, T.A.; Johnson, L.; Puettmann, M.; Lippke, B.; Oneil, E. Incorporating Uncertainty into a Life Cycle Assessment (LCA) Model of Short-Rotation Willow Biomass (Salix spp.) Crops. BioEnergy Res. 2014, 7, 48-59. [CrossRef]

35. You, F.; Wang, B.M. Life Cycle Optimization of Biomass-to-Liquid Supply Chains with Distributed-Centralized Processing Networks. Ind. Eng. Chem. Res. 2011, 50, 10102-10127. [CrossRef]

36. Budsberg, E.; Rastogi, M.; Puettmann, M.E.; Caputo, J.; Balogh, S.; Volk, T.A.; Gustafson, R.; Johnson, L. Life-Cycle Assessment for the Production of Bioethanol from Willow Biomass Crops via Biochemical Conversion. For. Prod. J. 2012, 62. Available online: http://search.ebscohost.com/login.aspx?direct=true\&profile=ehost\& scope $=$ site \&authtype $=$ crawler \&jrnl $=00157473 \& A N=85361701 \& \mathrm{~h}=$ ZkO1eG3nGlyZek $\% 2 B 191 C Y J X x u \%$ 2FH\%2BS\%2ByPY90Kvi7yScND8xVW\%2BST90\%2FSApSLhXlYIA\%2BLzI6wow89KYBamN5y8Gow\% 3D\%3D\&crl=c (accessed on 2 June 2014). [CrossRef]

37. Popp, A.; Dietrich, J.P.; Lotze-Campen, H.; Klein, D.; Bauer, N.; Krause, M.; Beringer, T.; Gerten, D.; Edenhofer, $\mathrm{O}$. The economic potential of bioenergy for climate change mitigation with special attention given to implications for the land system. Environ. Res. Lett. 2011, 6, 034017. [CrossRef]

38. Hsu, D.D.; Inman, D.; Heath, G.A.; Wolfrum, E.J.; Mann, M.K.; Aden, A. Life Cycle Environmental Impacts of Selected U.S. Ethanol Production and Use Pathways in 2022. Environ. Sci. Technol. 2010, 44, 5289-5297. [CrossRef]

39. Liu, W.; Wang, J.; Richard, T.L.; Hartley, D.S.; Spatari, S.; Volk, T.A. Economic and life cycle assessments of biomass utilization for bioenergy products. Biofuels Bioprod. Biorefining 2017, 11, 633-647. [CrossRef]

40. Lo, S.-L.; Ma, H.-W. Quantifying and reducing uncertainty in life cycle assessment using the Bayesian Monte Carlo method. Sci. Total Environ. 2005, 340, 23-33. [CrossRef] [PubMed]

41. Sonnemann, G.; Schuhmacher, M.; Castells, F. Uncertainty assessment by a Monte Carlo simulation in a life cycle inventory of electricity produced by a waste incinerator. J. Clean. Prod. 2003, 11, 279-292. [CrossRef]

42. Heijungs, R.; Huijbregts, M.A. A review of approaches to treat uncertainty in LCA. In Proceedings of the 2nd International Congress on Environmental Modelling and Software, Osnabrück, Germany, 14-17 June 2004.

43. Huijbregts, M.A.J. Uncertainty and variability in environmental life-cycle assessment. Int. J. Life Cycle Assess. 2002, 7, 173. [CrossRef] 
44. Huijbregts, M.A. Application of uncertainty and variability in LCA. Int. J. Life Cycle Assess. 2013, 3, 273. [CrossRef]

45. Geisler, G.; Hellweg, S.; Hungerbühler, K. Uncertainty analysis in life cycle assessment (LCA): Case study on plant-protection products and implications for decision making (9 pp +3 pp). Int. J. Life Cycle Assess. 2005, 10, 184-192. [CrossRef]

46. Guo, M.; Murphy, R. LCA data quality: Sensitivity and uncertainty analysis. Sci. Total Environ. 2012, 435, 230-243. [CrossRef]

47. Nguyen, L.; Cafferty, K.; Searcy, E.M.; Spatari, S. Uncertainties in Life Cycle Greenhouse Gas Emissions from Advanced Biomass Feedstock Logistics Supply Chains in Kansas. Energies 2014, 7, 7125-7146. [CrossRef]

48. Gold, S.; Seuring, S. Supply chain and logistics issues of bio-energy production. J. Clean. Prod. 2011, 19, 32-42. [CrossRef]

49. Sukumaran, R.K.; Surender, V.J.; Sindhu, R.; Binod, P.; Janu, K.U.; Sajna, K.V.; Rajasree, K.P.; Pandey, A. Lignocellulosic ethanol in India: Prospects, challenges and feedstock availability. Bioresour. Technol. 2010, 101, 4826-4833. [CrossRef]

50. Puri, M.; Abraham, R.E.; Barrow, C.J. Biofuel production: Prospects, challenges and feedstock in Australia. Renew. Sustain. Energy Rev. 2012, 16, 6022-6031. [CrossRef]

51. Hari, T.K.; Yaakob, Z.; Binitha, N.N. Aviation biofuel from renewable resources: Routes, opportunities and challenges. Renew. Sustain. Energy Rev. 2015, 42, 1234-1244. [CrossRef]

52. Zhao, X.; Brown, T.R.; Tyner, W.E. Stochastic techno-economic evaluation of cellulosic biofuel pathways. Bioresour. Technol. 2015, 198, 755-763. [CrossRef] [PubMed]

53. Zhang, Y.; Brown, T.R.; Hu, G.; Brown, R.C. Techno-economic analysis of two bio-oil upgrading pathways. Chem. Eng. J. 2013, 225, 895-904. [CrossRef]

54. U.S. Energy Information Administration. EIA-Electricity Data. EIA Independent Statistics and Analysis, 24 April 2020. Available online: https://www.eia.gov/electricity/monthly/epm_table_grapher.php?t=epmt_5_ 6_a (accessed on 30 April 2020).

55. U.S. Energy Information Administration. Electric Power Monthly-U.S. Energy Information Administration (EIA). Available online: https://www.eia.gov/electricity/monthly/epm_table_grapher.php (accessed on 16 November 2020).

56. Klein, J.; Rhyne, I.; Bender, S.; Jones, M. Comparative Costs of California Central Station Electricity Generation. CEC-200-2009-07SF, January 2010. Available online: http://large.stanford.edu/courses/2015/ph240/crane2/ docs/cec-200-2009-07sf.pdf (accessed on 16 November 2020).

57. Bauer, L. Biomass Pyrolysis Comes of Age. Biofuels Digest, 8 June 2017. Available online: https://www. biofuelsdigest.com/bdigest/2017/06/08/biomass-pyrolysis-comes-of-age/ (accessed on 21 June 2020).

58. Macrotrends LLC. WTI Crude Oil Prices-10 Year Daily Chart, Macrotrends. 2020. Available online: https: //www.macrotrends.net/2516/wti-crude-oil-prices-10-year-daily-chart (accessed on 12 November 2020).

59. Bioenergy Technologies Office. Multi-Year Program Plan; Department of Energy: Washington, DC, USA, 2016.

60. Klöpffer, W. Life cycle assessment. Environ. Sci. Pollut. Res. 1997, 4, 223-228. [CrossRef]

61. Wu, J.; Wang, J.; McNeel, J. Economic modeling of woody biomass utilization for bioenergy and its application in central Appalachia, USA. Can. J. For. Res. 2011, 41, 165-179. [CrossRef]

62. National Renewable Energy Laboratory. U.S. Life Cycle Inventory Database. 2012. Available online: https://www.lcacommons.gov/nrel/search (accessed on 19 November 2019).

63. Wang, Y.; Wang, J.; Schuler, J.; Hartley, D.; Volk, T.; Eisenbies, M. Optimization of harvest and logistics for multiple lignocellulosic biomass feedstocks in the northeastern United States. Energy 2020, 197, 117260. [CrossRef]

64. PRé Consultants. Introduction to LCA with SimaPro.pdf. January 2016. Available online: https://www.presustainability.com/legacy/download/SimaPro8IntroductionToLCA.pdf (accessed on 2 September 2019).

65. Wernet, G.; Bauer, C.; Steubing, B.; Reinhard, J.; Moreno-Ruiz, E.; Weidema, B.P. The ecoinvent database version 3 (part I): Overview and methodology. Int. J. Life Cycle Assess. 2016, 21, 1218-1230. [CrossRef]

66. Liu, W.; Zhang, Z.; Xie, X.; Yu, Z.; Von Gadow, K.; Xu, J.; Zhao, S.; Yang, Y. Analysis of the Global Warming Potential of Biogenic $\mathrm{CO}_{2}$ Emission in Life Cycle Assessments. Sci. Rep. 2017, 7, 39857. [CrossRef]

67. Boulay, A.-M.; Bouchard, C.; Bulle, C.; Deschênes, L.; Margni, M. Categorizing water for LCA inventory. Int. J. Life Cycle Assess. 2011, 16, 639-651. [CrossRef] 
68. Frischknecht, R.; Jungbluth, N.; Althaus, H.; Bauer, C.; Doka, G.; Dones, R.; Hischier, R.; Hellweg, S.; Humbert, S.; Köllner, T.; et al. Implementation of Life Cycle Impact Assessment Methods; Ecoinvent Report No. 3; Swiss Centre for Life Cycle Inventories: Dübendorf, Switzerland, 2007.

69. Frischknecht, R.; Wyss, F.; Knöpfel, S.B.; Lützkendorf, T.; Balouktsi, M. Cumulative energy demand in LCA: The energy harvested approach. Int. J. Life Cycle Assess. 2015, 20, 957-969. [CrossRef]

70. Frischknecht, R.; Heijungs, R.; Hofstetter, P. Einstein'ssons for energy accounting in LCA. Int. J. Life Cycle Assess. 1998, 3, 266-272. [CrossRef]

71. Žižlavský, O. Net Present Value Approach: Method for Economic Assessment of Innovation Projects. Procedia Soc. Behav. Sci. 2014, 156, 506-512. [CrossRef]

72. Mahmoudi, M.; Sowlati, T.; Sokhansanj, S. Logistics of supplying biomass from a mountain pine beetle-infested forest to a power plant in British Columbia. Scand. J. For. Res. 2009, 24, 76-86. [CrossRef]

73. Mobini, M.; Sowlati, T.; Sokhansanj, S. Forest biomass supply logistics for a power plant using the discrete-event simulation approach. Appl. Energy 2011, 88, 1241-1250. [CrossRef]

74. McKendry, P. Energy production from biomass (part 1): Overview of biomass. Bioresour. Technol. 2002, 83, 37-46. [CrossRef]

75. McKendry, P. Energy production from biomass (part 2): Conversion technologies. Bioresour. Technol. 2002, 83, 47-54. [CrossRef]

76. McKendry, P. Energy production from biomass (part 3): Gasification technologies. Bioresour. Technol. 2002, 83, 55-63. [CrossRef]

77. Anderson, V. Alternative Economic Indicators (Routledge Revivals); Routledge: London, UK, 2014.

78. Rubinstein, R.Y.; Kroese, D.P. Simulation and the Monte Carlo Method; John Wiley \& Sons: Hoboken, NJ, USA, 2016.

79. Löwgren, B.H.; Weigert, J.; Esche, E.; Repke, J.-U. Uncertainty Analysis for Data-Driven Chance-Constrained Optimization. Sustainability 2020, 12, 2450. [CrossRef]

80. Röder, M.; Whittaker, C.; Thornley, P. How certain are greenhouse gas reductions from bioenergy? Life cycle assessment and uncertainty analysis of wood pellet-to-electricity supply chains from forest residues. Biomass Bioenergy 2015, 79, 50-63. [CrossRef]

81. Rasheed, R.; Khan, N.; Yasar, A.; Su, Y.; Tabinda, A.B. Design and cost-benefit analysis of a novel anaerobic industrial bioenergy plant in Pakistan. Renew. Energy 2016, 90, 242-247. [CrossRef]

82. Jagannathan, R.; Matsa, D.A.; Meier, I.; Tarhan, V. Why Do Firms Use High Discount Rates? J. Financ. Econ. 2016, 120, 445-463. [CrossRef]

83. Spath, P.L.; Mann, M.K. Biomass Power and Conventional Fossil Systems with and without $\mathrm{CO}_{2}$ Sequestration-Comparing the Energy Balance, Greenhouse Gas Emissions and Economics; EERE Publication and Product Library: Washington, DC, USA, 2004; p. 38.

84. Hsu, D.D. Life cycle assessment of gasoline and diesel produced via fast pyrolysis and hydroprocessing. Biomass Bioenergy 2012, 45, 41-47. [CrossRef]

85. Steele, P.; Puettmann, M.E.; Penmetsa, V.K.; Cooper, J.E. Life-Cycle Assessment of Pyrolysis Bio-Oil Production. For. Prod. J. 2012, 62, 326-334. [CrossRef]

86. Cherubini, F.; Jungmeier, G. LCA of a biorefinery concept producing bioethanol, bioenergy, and chemicals from switchgrass. Int. J. Life Cycle Assess. 2010, 15, 53-66. [CrossRef]

87. Nuss, P.; Gardner, K.H.; Jambeck, J.R. Comparative Life Cycle Assessment (LCA) of Construction and Demolition (C\&D) Derived Biomass and U.S. Northeast Forest Residuals Gasification for Electricity Production. Environ. Sci. Technol. 2013, 47, 3463-3471. [PubMed]

88. Tidball, R.; Bluestein, J.; Rodriguez, N.; Knoke, S.; International, I.; Macknick, J. Cost and Performance Assumptions for Modeling Electricity Generation Technologies; National Renewable Energy Lab: Golden, CO, USA, 2010; p. 221.

89. Sultana, A.; Kumar, A.; Harfield, D. Development of agri-pellet production cost and optimum size. Bioresour. Technol. 2010, 101, 5609-5621. [CrossRef]

90. Swanson, R.M.; Platon, A.; Satrio, J.A.; Brown, R.C. Techno-economic analysis of biomass-to-liquids production based on gasification. Fuel 2010, 89, S11-S19. [CrossRef]

91. Zhang, X.; Wang, J.; Vance, J.; Wang, Y.; Wu, J.; Hartley, D.S. Data Analytics for Enhancement of Forest and Biomass Supply Chain Management. Curr. For. Rep. 2020, 6, 129-142. [CrossRef] 
Publisher's Note: MDPI stays neutral with regard to jurisdictional claims in published maps and institutional affiliations. (c)

(C) 2020 by the authors. Licensee MDPI, Basel, Switzerland. This article is an open access article distributed under the terms and conditions of the Creative Commons Attribution (CC BY) license (http://creativecommons.org/licenses/by/4.0/). 